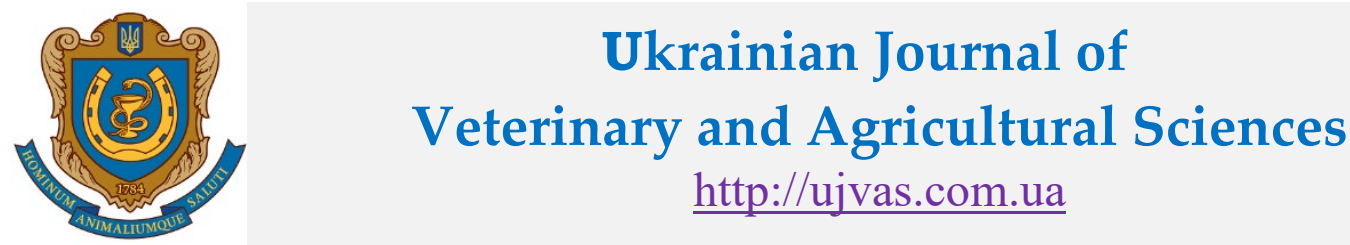

Stepan Gzhytskyi National University of Veterinary Medicine and Biotechnologies Lviv \begin{tabular}{l|l|l} 
original article & UDC 619.615 & doi: 10.32718/ujvas3-1.07
\end{tabular}

\title{
The influence of the preparation "Bendamin" on the morphological and biochemical indices of blood of rats in experimental modeling of heart failure
}

\author{
I. S. Varkholiak, B. V. Gutyj
}

Stepan Gzhytskyi National University of Veterinary Medicine and Biotechnologies, Pekarska Str., 50, Lviv, 79010, Ukraine

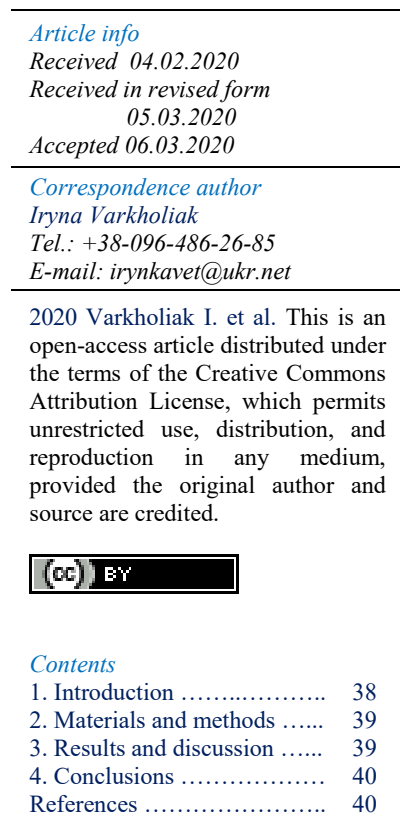

\begin{abstract}
The purpose of this work was to study the influence of "Bendamin" on the morphological and biochemical indices of rat blood in experimental modeling of heart failure. The investigation were performed on white sexually mature young male-rats of Wistar line weighing 180-200 g, kept at the standard ration of the institute vivarium of the State Research Institute of Veterinary Preparations and Fodder Additives. To create a model of doxorubicininduced cardiomyopathy, 24 male rats were selected. Animals were divided into 3 groups of 6 animals in each: control group - intact animals; experimental group $\mathrm{E}_{1}$, in which animals were modeled doxorubicin-induced cardiomyopathy by intraperitoneal injected of doxorubicin at a dose of $2.5 \mathrm{mg} / \mathrm{kg} 3$ times a week for two weeks; experimental group $\mathrm{E}_{2}$, in which animals, after injection of doxorubicin, the preparation "Bendamin" was injected in the dose $20 \mathrm{mg} / \mathrm{kg}$ intragastrically. For experimental modeling of heart a decrease in the number of red blood cells was found in the blood of rats of the first experimental group by $34.7 \%$ and hemoglobin level - by $24.2 \%$, with a simultaneous increase in the average hemoglobin content in one erythrocyte by $16.2 \%$. Doxorubicininduced cardiomyopathy in rats of the first experimental group was accompanied by a decrease in leukocyte count by $22.2 \%$, an increase in uric acid level by almost in 2 times, creatinine by $11.4 \%$, cholesterol by $61.1 \%$. In the research of the protein synthesizing function of the liver of rats in experimental modeling of heart failure, a decrease in total protein by $9.6 \%$ was found. These changes were accompanied by a slight decrease in albumin levels and a slight increase in globulin levels. By intoxication with doxorubicin, rats of the first experimental group showed a violation of the functional state of the liver, indicating an increase in the activity of aminotransferases in their blood, namely: AlAT by $34.2 \%$, AsAT - by $21.7 \%$, accordingly. Positive action of cardio preparation "Bendamin" on rats organism under conditions of creation of a model of doxorubicin-induced cardiomyopathy was installed, manifested by the normalization of hematological and biochemical parameters, functional status and protein synthesis of the liver.
\end{abstract}

Key words: pharmacology, "Bendamin" preparation, rats, heart failure, cardiomyopathy.

\section{Citation:}

Varkholiak, I. S., \& Gutyj, B. V. (2020). The influence of the preparation "Bendamin" on the morphological and biochemical indices of blood of rats in experimental modeling of heart failure. Ukrainian Journal of Veterinary and Agricultural Sciences, 3(1), 38-41.

\section{Introduction}

Cardiology is one of the directions of veterinary medicine which is most intensively developing. Annually, a large number of new investigations are conducted in the world, based on the results of which refine the views on the treatment of cardiovascular diseases (Varkholiak \& Gutyj, 2018). Recently, our ideas about the pathogenetic mechanisms of heart failure have changed significantly, and new approaches to its therapy are being developed (Tjostheim et al., 2019; Oldach et al., 2019).

Cardiac and vascular pathologies in dogs and cats are extremely diverse and fairly common in the daily practice of a veterinarian in Ukraine and beyond. According to the classification of Professor G. V. Domrachev, in domestic animals, cardiovascular pathology is divided into diseases of the myocardium, pericardium, endocardium and diseases of the blood vessels. There is a close relationship between the above pathologies, age and animal breeds (Undhad et al., 2012; Varkholiak, 2016; Zhulikova, 2016; Yata et al., 2019).

According to foreign authors, cardiovascular pathology is about $10.0 \%$ of all pathologies of the internal organs.

During 2014-2018, pets with the following pathologies were coming in at the "DoctorVET" in Animal Health Center of Lviv: cardiomyopathy (dilatation, hypertrophic, arrhythmogenic), MK endocardiosis, isolated cases of birth defects, and also pericarditis.

In recent years, several significant investigations have been conducted in the field of treatment of heart failure, new diagnostic techniques were introduced, the genetic features of particular pathologies were identified, and new medicines appeared, such as pimobendan, polyunsaturated fatty acids, sildenafil, levosimendan, torasemide, nebivolol, lisinopril, clopidogrel, and some others. However, data on the use of 
new therapeutic means in cardiovascular pathology is not enough (Trofimjak \& Slivinska, 2016; Varkholiak \& Gutyj, 2019; Varcholyak \& Gutyi, 2019).

Thus, there is a reasonable need to develop, conduct comprehensive investigations of the mechanisms of action of the medicines, its interaction with other preparations, clinical efficiency of treatment and safety of animals in the development of cardiovascular pathology.

The purpose of the work is to investigate the influence of cardio preparation "Bendamin" on the morphological and biochemical indices of rat blood in experimental modeling of heart failure.

\section{Materials and methods}

The investigations were performed on white sexually mature young rats-males of the Wistar line weighing 180$200 \mathrm{~g}$, which were kept on a standard ration of the institute vivarium of the State Research Institute of Veterinary Preparations and Feed Additives. Throughout the experiment, rats were kept in a balanced ration containing all the necessary components, and animals were provided with drinking water without restrictions from 0.2 liter glass bowls.

The experimental investigations were conducted in accordance with the requirements of the biological-biological experiment for the selection of analogues, setting control, compliance with the same feeding conditions and retention during the experiment and the results.

To create a model of doxorubicin-induced cardiomyopathy, 24 male rats were selected. Animals were divided into 3 groups of 6 animals in each: control group - intact animals; experimental group $E_{1}$, in which animals were modeled doxorubicin-induced cardiomyopathy by intraperitoneal introduction of doxorubicin at a dose of $2.5 \mathrm{mg} / \mathrm{kg} 3$ times a week for two weeks; experimental group $\mathrm{E}_{2}$, in which animals were injected intragastrically with "Bendamin" at a dose of $20 \mathrm{mg} / \mathrm{kg}$.

Morphological and biochemical indices of blood were investigated by the method (Vlizlo et al., 2012).

All animal manipulations were carried out in accordance with the European Convention for the Protection of Vertebrate Animals, which is used for experimental and scientific purposes (Strasbourg, 1986).

Analysis of the research results was performed using the Statistica 6.0 software package. The probability of differences was evaluated by Student's t-test. The results were considered probable at $\mathrm{P} \leq 0.05$.

\section{Results and discussion}

In experimental modeling of heart failure by intraperitoneal injection of doxorubicin at a dose of $2.5 \mathrm{mg} / \mathrm{kg} 3$ times a week for two weeks, was found reducing the number of erythrocytes in the blood of rats of the first experimental group by $34.7 \%$ and hemoglobin level - by $24.2 \%$, with a simultaneous increase in the average hemoglobin content in one erythrocyte by $16.2 \%$ (Table. 1 ). These changes may be related to the negative action of oxidative stress on cardiomyocytes.
In the search of the above mentioned indices in the blood of the experimental group $\mathrm{E}_{2}$ an increase in the number of erythrocytes and hemoglobin level compared with sick animals was observed. It should be noted that the number of erythrocytes in the blood of rats treated with the preparation "Bendamin" ranged from $7.14 \pm 0.547 \mathrm{~T} / 1$, whereas in rats of the first experimental group this indicator was $4.94 \pm 0.125 \mathrm{~T} / \mathrm{l}$. In the research of hemoglobin in the blood of rats in the experimental groups, their increase is found in the second experimental group of rats compared to the first experimental group, however, when compared with the control group, this indicator was lower by $5.7 \%$, respectively.

The average hemoglobin content in one erythrocyte was higher in the first experimental group, where it was respectively $17.71 \pm 1.10 \mathrm{pg}$, slightly lower was in the second experimental group.

Doxorubicin-induced cardiomyopathy in rats of the first experimental group was accompanied by a decrease in leukocyte number by $22.2 \%$, which may be related to a decrease in immunity and inhibition of leukocyte formation in the bone marrow against the background of oxidative stress caused by the injection of doxorubicin.

When using the preparation "Bendamin" to experimental rats under the conditions of experimental modeling of heart failure was found an increase of their number to $6.58 \pm 0.55 \mathrm{G} / 1$, which is $26.3 \%$ higher than the indices of the first experimental group.

In order to evaluate the influence of preparation "Bendamin" in simulated doxorubicin-induced cardiomyopathy, on kidney condition was determined by such indicators as uric acid and creatinine levels. It was Installed, that in the first experimental group of rats uric acid levels were increased almost in 2-times, whereas creatinine levels were increased by $11.4 \%$. The lowest level of uric acid was in the experimental group $E_{2}$, which along with the intoxication of doxorubicin were used the preparation "Bendamin". Similar changes are observed in the research of creatinine level, which in the experimental group $\mathrm{E}_{2}$ was fluctuated respectively within $50.4 \pm 1.54 \mu \mathrm{mol} / \mathrm{l}$, whereas in the control group of rats this indicator was $49.0 \pm 1.07 \mu \mathrm{mol} / \mathrm{l}$. These changes in the blood of the second experimental group indicate a partial normalization of renal function.

We found that in modeling heart failure in the experimental animals of the first experimental group there was an increase in cholesterol level by $61.1 \%$ compared with the control group. It should be noted that when using the preparation "Bendamin" cholesterol level was decreased by $36.3 \%$ and reached physiological values.

Reorientation of oxidative metabolism in the myocardium to the anaerobic pathway as a result of rats intoxication with doxorubicin and damage to their heart muscle was reflected by a $59 \%$ increase in the creatine phosphokinase $\mathrm{MB}$ activity in the rats serum of the first experimental group compared with indicators taken from the control group of rats. This enzyme is a specific and sensitive marker of myocardial damage. 
Table 1

Morphological and biochemical indices of blood of rats in experimental modeling of heart failure and action of the preparation "Bendamin" ( $\mathrm{M} \pm \mathrm{m}, \mathrm{n}=6)$

\begin{tabular}{lccc}
\hline & \multicolumn{3}{c}{ Groups of animals } \\
\cline { 2 - 4 } \multicolumn{1}{c}{ Indicators } & Control & Experimental 1 & Experimental 2 \\
\hline Erythrocytes, $\mathrm{T} / \mathrm{l}$ & $7.57 \pm 0.349$ & $4.94 \pm 0.125^{*}$ & $7.14 \pm 0.547$ \\
Hemoglobin, $\mathrm{g} / \mathrm{l}$ & $115.4 \pm 2.9$ & $87.5 \pm 2.0^{*}$ & $110.6 \pm 3.2$ \\
The average hemoglobin content in one erythrocyte, $\mathrm{pg}$ & $15.24 \pm 1.14$ & $17.71 \pm 1.10^{*}$ & $15.49 \pm 1.15$ \\
Leukocytes, G/l & $6.70 \pm 0.62$ & $5.21 \pm 0.75^{*}$ & $6.58 \pm 0.55$ \\
Creatinine, $\mu \mathrm{mol} / \mathrm{l}$ & $49.0 \pm 1.07$ & $54.6 \pm 2.27^{*}$ & $50.4 \pm 1.54$ \\
Cholesterol, $\mathrm{mmol} / \mathrm{l}$ & $1.90 \pm 0.072$ & $3.06 \pm 0.057^{*}$ & $1.95 \pm 0.072$ \\
Uric acid, $\mu \mathrm{mol} / \mathrm{l}$ & $83.4 \pm 3.60$ & $164.2 \pm 4.11^{*}$ & $91.3 \pm 5.35$ \\
LDH, mmk/l & $1.93 \pm 0.20$ & $1.85 \pm 0.15$ & $2.10 \pm 0.30$ \\
Creatine phosphokinase MB, in units/l & $78 \pm 3.1$ & $124 \pm 4.3^{*}$ & $105 \pm 3.9$ \\
\hline
\end{tabular}

The injection of the cardio preparation to the experimental rats contributed to a slight decrease in creatine phosphokinase MB activity by $15.3 \%$ compared with the first experimental group.

One of the major enzymes involved in glycolysis reactions is lactate dehydrogenase. Based on the conducted research, it was found that LDH activity in the blood of rats of the first experimental group decreased by $4 \%$ due to doxorubicin intoxication. When using the "Bendamin" cardio preparation, to rats of the $\mathrm{E}_{2}$ experimental group were found the increase of this enzyme compared to the control and the first experimental group, here, accordingly, LDH activity ranged from $2.10 \pm 0.30 \mathrm{mmk} / \mathrm{l}$.

In the research of the protein synthesizing function of rat liver in experimental modeling of heart failure and the action of the "Bendamin" cardio preparation reduced the total protein in the first experimental group by $9.6 \%$, of the second experimental group - by $2.3 \%$ compared with the control group (Table 2).

\section{Table 2}

Protein synthesizing function of rat liver in experimental modeling of heart failure and action of "Bendamin" preparation $(\mathrm{M} \pm \mathrm{m}, \mathrm{n}=6)$

\begin{tabular}{lccc}
\hline \multicolumn{1}{c}{ Indices } & \multicolumn{3}{c}{ Groups of animals } \\
\cline { 2 - 4 } & Control & Experimental 1 & Experimental 2 \\
\hline Total protein, g/l & $62.31 \pm 3.12$ & $56.32 \pm 3.57^{*}$ & $60.84 \pm 2.78$ \\
Albumin, g/l & $24.12 \pm 2.18$ & $17.57 \pm 3.34^{*}$ & $22.67 \pm 2.45$ \\
Globulins, g/l & $38.19 \pm 3.41$ & $38.75 \pm 4.10$ & $38.17 \pm 3.11$ \\
\hline
\end{tabular}

These changes were accompanied by a slight decrease in albumin levels and a slight increase in globulin levels, the level of albumins and globulins was thus set at $17.57 \pm 3.34$ and $38.75 \pm 4.10 \mathrm{~g} / 1$ in the first experimental group versus $24.12 \pm 2.18$ and $38.19 \pm 3.41$ in the control group of rats.
By intoxication with doxorubicin in rats of the first experimental group was found violations of the functional state of the liver which is indicated by increased activity of aminotransferases in their blood, namely: AlAT by $34.2 \%$, AsAT - by $21.7 \%$, respectively (Table 3 ).

\section{Table 3}

Functional state of rat liver in experimental modeling of heart failure and action of the preparation "Bendamin" $(\mathrm{M} \pm \mathrm{m}, \mathrm{n}=6)$

\begin{tabular}{|c|c|c|c|}
\hline \multirow[b]{2}{*}{ Indices } & \multicolumn{3}{|c|}{ Groups of animals } \\
\hline & Control & Experimental 1 & Experimental 2 \\
\hline $\mathrm{AlAT}$, un/l & $38.47 \pm 2.10$ & $51.62 \pm 3.57^{*}$ & $38.50 \pm 2.10$ \\
\hline $\mathrm{AlAT}$, un/1 & $188.5 \pm 15.86$ & $229.4 \pm 10.30 *$ & $189.2 \pm 11.25$ \\
\hline
\end{tabular}

The use of the preparation "Bendamin" in experimental rats under experimental modeling of heart failure, was set up a decrease in the activity of aminotransferases in serum of experimental group $E_{2}$. Thus, the activity of AlAT and AsAT in the serum of the second experimental group was decreased by 25.4 and $17.5 \%$, respectively, compared to the intoxicated rats, who were not given a cardiac preparation.

\section{Conclusions}

Based on our research, positive action of "Bendamin" cardio preparation on rats organism was set up under the conditions of creation of a doxorubicin-induced cardiomyopathy model, that appears itself by the normalization of hematological and biochemical indices, functional status and protein synthesis function of the liver.

\section{References}

Oldach, M. S., Ueda, Y., Ontiveros, E. S., Fousse, S. L., Harris, S. P., \& Stern, J. A. (2019). Cardiac Effects of a Single Dose of Pimobendan in Cats With Hypertrophic Cardiomyopathy; A Randomized, Placebo-Controlled, Crossover Study. Front Vet Sci., 6, 15. doi: 10.3389/fvets.2019.00015. 
Tjostheim, S. S., Kellihan, H. B., Grint, K. A., \& Stepien, R. L. (2019). Effect of sildenafil and pimobendan on intracardiac heartworm infections in four dogs. J Vet Cardiol., 23, 96-103. doi: 10.1016/j.jvc.2019.02.001.

Trofimjak, R., \& Slivinska, L. (2016). Diagnosis of chronic heart failure dogs - existing methods and future prospects. Scientific Messenger of LNU of Veterinary Medicine and Biotechnologies. Series: Veterinary Sciences, 18(3(71), 130133. doi: $10.15421 /$ nvlvet7129.

Undhad, V. V., Fefar, D. T., Jivani, B. M., Gupta, H., Ghodasara, D. J., Joshi, B. P. \& Prajapati, K. S. (2012). Cardiac troponin: an emerging cardiac biomarker in animal health. Vet. World, 5, 508-511. doi: 10.5455/vetworld.2012.508-511.

Varcholyak, I. S., \& Gutyi, B. V. (2019). Determination of the chronic toxicity of preparation "Bendamin" on laboratory animals. Theoretical and Applied Veterinary Medicine, 7(2), 63-68. doi: 10.32819/2019.71011.

Varkholiak, I. S. (2016). The usage of medicines at the cardiovascular pathologies in dogs and cats. Scientific Messenger LNUVMBT named after S.Z. Gzhytskyj, 18, 3(71), 261-265. https://nvlvet.com.ua/index.php/journal/article/view/974.

Varkholiak, I. S., \& Gutyj, B. V. (2018). Determination of acute toxicity of "Bendamin" drug in laboratory animals. Scientific Mes- senger of Lviv National University of Veterinary Medicine and Biotechnologies, 20(92), 209-212. doi: 10.32718/nvlvet9243.

Varkholiak, I. S., \& Gutyj, B. V. (2019). The degree of cumulation of the "Bendamin" drug in the body of white rats. Scientific Messenger of Lviv National University of Veterinary Medicine and Biotechnologies. Series: Veterinary sciences, 21(94), 8285. doi: $10.32718 /$ nvlvet 9415.

Vlizlo, V. V., Fedoruk, R. S., \& Raty`ch, I. B. (2012). Laboratorni metody` doslidzhen' u biologiyi, tvary`nny`cztvi ta vetery`narnij medy`cy`ni: dovidny`k. L`viv: Spolom (in Ukrainian).

Yata, M., Kooistra, H. S., \& Beijerink, N. J. (2019). Cardiorenal and endocrine effects of synthetic canine BNP1-32 in dogs with compensated congestive heart failure caused by myxomatous mitral valve disease. J Vet Intern Med., 33(2), 462-470. doi: 10.1111/jvim.15416.

Zhulikova, O.A. (2016). Monitoring rasprostranenija serdechnososudistyh zabolevanij sredi koshek i sobak v g. Blagoveshhensk amurskoj oblasti. Dal'nevostochnyj agrarnyj vestnik, 2(38), 49-56. https://cyberleninka.ru/article/n/monitoring-rasprostraneniyaserdechno-sosudistyh-zabolevaniy-sredi-koshek-i-sobak-v-gblagoveschensk-amurskoy-oblasti (in Russian). 